\title{
PENGARUH PERASAN DAUN BABADOTAN (Ageratum conyzoides) SEBAGAI REPELLENT TERHADAP DAYA HINGGAP NYAMUK Aedes aegypti DI LOKA LITBANG P2B2 CIAMIS TAHUN 2015
}

\author{
Welas Indrasari ${ }^{1)}$, Hari Rudijanto Indro Wardono ${ }^{2)}$ \\ Jurusan Kesehatan Lingkungan, Politeknik Kesehatan Kemenkes Semarang, \\ Jl.Raya Baturaden KM 12 Purwokerto, Indonesia
}

\begin{abstract}
Abstrak
Demam Berdarah Dengue (DBD) di Indonesia menjadi masalah kesehatan masyarakat dan merupakan penyakit endemis hampir di seluruh provinsi. Salah satu alternatif yang berpotensi untuk mengendalikan populasi vektor nyamuk Aedes aegypti adalah menggunakan insektisida. Daun babadotan mengandung saponin, flavanoid, fenol dan minyak atsiri sehingga dapat dijadikan sebagai insektisida alami. Tujuan penelitian ini adalah menghitung konsentrasi perasan daun babadotan(Ageratum conyzoides) yang paling efektif sebagai repellent nyamuk Aedes aegypti. Metode dalam penelitian ini adalah true experimental (eksperimen sesungguhnya) dan data di analisis menggunakan anova dan post hoc test.Hasil penelitian perasan daun babadotan (Ageratum conyzoides) menunjukan terdapat perbedaan jumlah nyamuk yang hinggap pada berbagai konsentrasi, konsentrasi $100 \%$ pada jam kedua mempunyai daya proteksi sebesar 96,96\% dan nilai signifikasi 0,000 (<0,005) yang berarti terdapat perbedaan jumlah nyamuk hinggap pada berbagai konsentrasi perasan yang digunakan.Berdasarkan hasil tersebut, terlihat bahwa perasan daun babadotan (Ageratum conyzoides) dapat digunakan sebagai penolak nyamuk Aedes aegypti. Di sarankan untuk peneliti selanjutnya melakukan uji lanjutan seperti repellent perasan babadotan diganti menjadi ekstrak dan hanya menguji efektifitas kandungan minyak atsiri sebagai daya tolak nyamuk.
\end{abstract}

Kata kunci : Repellent, Aedesagypti, Daun Babadotan (Ageratum conyzoides) dan kesehatan lingkungan

\section{Abstract}

[INFLUENCE OF DISTILLATION BABADOTAN LEAF (Ageratum conyzoides) AS REPELLENT ABOUT ALIGHT ENERGY OF MOSQUITO Aedes aegypti 2015] Dengue fever (DBD) in Indonesia became problem of public health and was endemic disease almost all provinces. One of alternative that potentially to control population of mosquito vector Aedes aegypti was used insecticides. Using of chemical insecticides have a negative impact on the body. Babadotan leaf contains saponin, flavanoida, fenol and oil volatile so it can be used as natural insecticide. The purpose of this research is to know effectiveness of distillation babadotan leaf (Ageratum conyzoides) as repellent of Aedes aegypti mosquito on the concentration of 20\%, 60\%, and 100\% during 3 hours. The method of this research is true experimental (real experiment) and data was analyzed with anova. The result of distillation babadotan leaf (Ageratum conyzoides) showed that there are difference number of mosquito which alight on concentration of distillation with significant value 0,000 (<0,005) that mean there are difference number of mosquito that alight on various concentration that used. Based on this result, can seen that distillation of babadotan leaf (Ageratum conyzoides) can used as repellent of Aedes aegypti mosquito. Was suggested for researcher furthermore to do continuation experiment such as repellent of babadotan distillation was substituted with extract and only examine of effectiveness oil volatile as repellent of mosquito.

Keywords : Repellent, Aedes aegypti, Daun Babadotan (Ageratum conyzoides), and environmental health

\section{PENDAHULUAN}

Menurut PP No 66 Tahun 2014 pasal 1 tentang Kesehatan Lingkungan adalah upaya pencegahan penyakit dan atau gangguan kesehatan dari faktor resiko lingkungan untuk mewujudkan kualitas lingkungan yang sehat baik dari aspek fisik, kimia, biologi, maupun sosial. Permenkes RI No.394/MENKES/PER/III/2010 Pasal 5 tentang Pengendalian Vektor berisi pengendalian vektor dapat dilakukan dengan pengolahan lingkungan secara fisik atau mekanis, penggunaan agen biotik, kimiawi baik terhadap vektor maupun tempat perkembangbiakannya dan/atau perubahan perilaku masyarakat serta dapat mempertahankan dan mengembangkan kearifan lokal sebagai alternatif.

Demam Berdarah Dengue (DBD) di Indonesia menjadi masalah kesehatan masyarakat dan merupakan penyakit endemis hampir di seluruh 
provinsi. Angka kesakitan DBD tahun 2013 tercatat 45,85 per 100.000 penduduk (112.511 kasus) dengan angka kematian sebesar $0,77 \%$ (871 kematian). Pada tahun 2014 sampai bulan April tercatat angka kesakitan DBD sebesar 5,17 per 100.000 penduduk (13,031 kasus) dengan angka kematian sebesar 0,84\% (110 kematian) (Ditjen PP \& PL Depkes RI, Kemenkes RI,2014). Pada tahun 2013, jumlah penderita DBD Provinsi Jawa Tengah mencapai 7.166 (Kemenkes RI,2013). Data yang di peroleh dari Dinas Kesehatan Kabupaten Banyumas tahun 2013 tercatat 471 kasus sampai bulan Desember (Dinas Kesehatan Kabupaten Banyumas,2013).

Pada saat ini alternatif pengendalian vektor yang murah, praktis dan relatif aman terhadap lingkungan. Salah satu alternatif tersebut adalah dengan digantikannya pestisida kimia dengan pestisida nabati, yaitu pestisida yang dibuat dari senyawa kimia yang terdapat dalam tumbuh-tumbuhan, sehingga tidak mencemari lingkungan dan relatif aman bagi manusia dan ternak. Selain itu pestisida nabati dapat juga digunakan sebagai bahan penolak (repellent) pada nyamuk (Agus Kardinan,2005,h.4). Peneliti merumuskan masalah peneliti "Berapakah konsentrasi daya tolak Perasan Daun Babadotan (Ageratumconyzoides) yang efektif terhadap nyamuk Aedes aegypti dan konsentrasi 20\%, 60\%, dan $100 \%$ selama 3 jam.

Tujuan peneliti adalah menghitung konsentrasi perasan daun babadotan (Ageratum conyzoides) yang paling efektif sebagai repellent nyamuk Aedes aegypti.

\section{BAHAN DAN CARA}

Jenis penelitian ini adalah eksperimen dengan kualifikasi true eksperimental design. Desain penelitian yang di pilih the posttest-only control group design.

Populasi dalam penelitian ini adalah seluruh nyamuk Aedes aegypti dan sampel penelitian ini adalah nyamuk Aedes aegypti pada tiap penelitian menggunakan 3 kurungan nyamuk sebagai tempat uji. Setiap kurungan nyamuk terdapat 25 nyamuk Aedesaegypti. Pengujian dilakukan selama 3 jam dengan melihat daya proteksi masing-masing perlakuan. Analisis data yang digunakan adalah Anova dan Post Hoc Test.

\section{III.HASIL DAN PEMBAHASAN}

\section{Hasil}

Jenis nyamuk yang digunakan dalam penelitian ini yaitu Aedes aegyptiyang diperoleh dari pengembangbiakan dari telur nyamuk menjadi nyamuk Aedes aegyptibetina dewasa. Jumlah nyamuk yang digunakan dalam penelitian ini sebanyak 75 ekor nyamuk dan masing- masing kandang berisi 25 nyamuk.

Tangan uji yang digunakan dalam penelitian ini adalah tangan uji dari rekan-rekan peneliti di Loka
Litbang P2B2 Ciamis. Bagian tangan yang digunakan untuk diolesi perasan yaitu bagian lengan tangan.

Konsentrasi $20 \%$ memiliki kemampuan menolak nyamuk Aedes aegypti yang rendah. Dari jam ke-1 sampai jam ke-4 daya proteksi tertinggi 58,82 dan daya proteksi terendah $25,92 \%$ pada jam ke-3, jadi untuk konsentrasi $20 \%$ tidak dapat menolak nyamuk dengan baik

Konsentrasi $60 \%$ memiliki kemampuan menolak nyamuk Aedes aegypti yang cukup bagus. Dari jam ke-1 sampai jam ke-4 daya proteksi t naik turun, daya proteksi tertinggi $81,17 \%$ pada jam ke-1 sampai jam ke-3 turun dan pada jam ke-4 daya proteksi naik menjadi $56,70 \%$.

Konsentrasi $100 \%$ memiliki kemampuan menolak nyamuk Aedes aegypti yang baik. Daya proteksi 73,30 pada jam ke-1 kemudian naik menjadi $96,96 \%$ pada jam ke-2 pada jam ke-3 dan jam ke-4 turun.

Hasil Homogeneityof variances menunjukan nilai sig $0.880>0,05$ sehingga data hasil riset merupakan data yang homogen ini merupakan persyaratan uji Anova

Hasil uji Anova di dapatkan hasil bahwa $\mathrm{F}=$ 9,586 dengan nilai signifikasi $=0,000$ karena $<0,05$ maka HO di tolak berarti terdapat perbedaan yang signifikan, daya proteksi antara kontrol, 20\%, 60\%, $100 \%$ jika dibedaan akan menghasilkan hasil yan signifikan.

Hasil uji Post Hoc Test menujukan nilai signifikan antara berbagai konsentrasi perasan daun babadotan.

\section{Pembahasan}

Jenis nyamuk yang digunakan dalam penelitian ini yaitu nyamuk Aedes aegyptibetina diperoleh dari ruang rearing nyamuk (tempat perkembangbiakan nyamuk) Loka Litbang P2B2 Ciamis sesuai dengan umur nyamuk yang telah disiapkan yaitu berumur 3-5 hari dengan kondisi steril (tidak mengandung virus yang menyebabkan penyakit. Jumlah nyamuk yang digunakan untuk penelitian ini sebanyak 75 nyamuk yang disediakan oleh Loka Litbang P2B2 Ciamis. Nyamuk yang akan digunakan sebagai penelitian ditangkap sehari sebelum penelitian dilaksanakan. Nyamuk yang sudah ditangkap dimasukan kedalam kandang berisi 25 ekor nyamuk. Nyamuk tersebut tidak beri makan sampai penelitian ini dilakukan. Hal tersebut dilakukan karena untuk memastikan kondisi nyamuk benar-benar lapar pada saat penelitian.

Mengujikan perasan daun babadotan (Ageratum conyzoides) dengan konsentrasi yang berbeda-beda peneliti dibantu oleh 2 orang rekan peneliti yang bersedia untuk diujikan tangannya dioleskan perasan daun babadotan dengan tingkat konsentrasi yang berbeda-beda, lalu dipaparkan pada kurungan nyamuk. Setiap konsentrasi yang digunakan menggunakan tangan yang sama. Contohnya tangan yang digunakan untuk mengujikan konsentrasi $20 \%$ digunakan juga untuk perlakuan replikasinya. Setiap kali perlakuan yang dilakukan pada lengan uji diikuti 
pula perlakuan pada lengan kontrol pada kurungan nyamuk. Setelah pengujian dilakukan, tangan uji dicuci bersih tanpa menggunakan sabun untuk menghindari kontaminasi bau dari sabun pada tangan uji dan dibersihkan menggunakan lap kering. Tangan uji yang diolesi perasan daun babadotan tidak mengalami reaksi panas, perih atau gatal, sehingga perasan daun babadotan aman digunakan sebagai repellent nyamuk.

Jumlah nyamuk Aedes aegypti yang hinggap pada tangan uji maupun tangan kontrol sangat bervariasi tergantung dari tingkat konsentrasi yang digunakan sebagai repellent. Pada Konsentrasi $20 \%$ dan konsentrasi $60 \%$ dapat terlihat beberapa jumlah nyamuk pada kontrol menunjukan angka yang lebih banyak sedangkan pada perlakuan menunjukan angka yang lebih sedikit Hal itu disebabkan karena tangan uji kontrol tidak menggunakan perasan

Berdasarkan semua konsentrasi yang telah diujikan didapat hasil bahwa jumlah nyamuk yang hingap terendah terdapat pada konsentrasi $100 \%$. Hasil rata-rata tersebut diketahui dari pembacaan hasil analisis One Way Anova. Pada pemaparan tangan uji dengan menggunakan konsentrasi $100 \%$ dilihat pada tabel uji daya proteksi repellent dapat diketahui bahwa pada jam ke-2 rata-rata nyamuk yang hinggap sebesar 0,1 .

Dalam aplikasinya, Shri J.N (2003) mengatakan daya repellent dipengaruhi oleh beberapa faktor antara lain: jenis spesies yang menggigit, kepadatan populasi vektor, umur pengguna repellent, tingkat aktifitas, suhu, kelembaban, hembusan angin dan paparan angin. Proses penolakan terhadap nyamuk karena penggunaan repellent dapat diterangkan sebagai berikut; minyak atsiri yang dioleskan merata ditangan pengguna akan meresap ke pori-pori kulit, lalu karena panas tubuh, minyak atsiri akan menguap ke udara. Bau ini akan terdeteksi oleh reseptor kimia (chemoreceptor) yang terdapat pada antena nyamuk dan diteruskan ke impuls saraf. Bau dari minyak atsiri ini tidak disukai nyamuk. Hal itulah yang kemudian diterjemahkan ke dalam otak nyamuk sehingga nyamuk akan mengekspresikan untuk menghindar dari sumber bau. Nyamuk memilih menghindar dan membatalkan arah dari lengan atau bagian tubuh pengguna repellent, mencari sumber makanan di tempat lain.

Hasil dari penelitian ini menunjukan bahwa perasan daun babadotan (Ageratum conyzoides) dapat digunakan sebagai bahan penolak nyamuk Aedes aegypti data daya proteksi diperoleh dari pengamatan setiap 10 detik dengan pengulangan 10 kali pada setiap jamnya selama 3 jam. Hasil dari pengamatan yang dilakukan secara organoleptik menunjukan bahwa tangan uji telah diolesi perasan daun babadotan (Ageratum conyzoides) dengan konsentrasi $100 \%$ dapat menolak nyamuk lebih baik dibandingkan dengan konsentrasi 20\% dan 60\%. Dari hasil penelitian tersebut, terlihat bahwa perasan daun babadotan (Ageratum conyzoides) dapat digunakan sebagai penolak nyamuk.

Pada analisis anova membuktikan ada beda dari berbagai konsentrasi yang diujikan. Konsentrasi $100 \%$ mempunyai perbedaan yang signifikan dibandingkan dengan konsentrasi $20 \%$ dan $60 \%$. Masing-masing konsentrasi mempunyai nilai signifikasi yang berbeda-beda.

Menurut peneliti konsentrasi $100 \%$ merupakan konsentrasi yang paling efektif. Faktor yang berpengaruh terhadap daya hinggap nyamuk yaitu kondisi tangan uji probandus, jam baiting nyamuk Aedes aegypti, kondisi nyamuk uji.

Berdasarkan hasil diatas dapat membuktikan hipotesis bahwa terdapat perbedaan daya tolak antar penggunaan berbagai konsentrasi perasan daun babadotan (Ageratum conyzoides) dengan konsentrasi $20 \%, 60 \%$ dan $100 \%$ terhadap nyamuk Aedes aegypti selama 3 jam. Pada tabel didapat hasil yang paling kecil. Hal tersebut membuktikan bahwa perasan daun babadotan dapat digunakan sebagai repellent.

\section{IV.KESIMPULAN}

\section{Kesimpulan}

Rata-rata daya proteksi nyamuk pada konsentrasi $20 \%$ daya proteksi tertinggi sebesar $58,82 \%$, pada konsentrasi $60 \%$ daya proteksi tertinggi sebesar $81,17 \%$, dan pada $100 \%$ rata-rata daya proteksi tertinggi sebesar $96,96 \%$

Konsentrasi $100 \%$ merupakan konsentrasi yang paling efektif pada jam ke-2 dan mengalami fluktuasi pada jam berikutnya.

\section{Saran}

Peneliti menyarankan untuk dilakukan uji lanjutan seperti repellent perasan babadotan diganti menjadi ekstrak dan hanya menguji efektifitas kandungan minyak atsiri sebagai daya tolak nyamuk.

\section{DAFTAR PUSTAKA}

Agus Kardinan. 2002. Pestisida Nabati Ramuan dan Aplikasi. Jakarta : PT. Penebar Swadaya.

Agus Kardinan. 2006. Tanaman Pengusir dan Pembasmi Nyamuk. Tangerang : Agro Media Pustaka.

Arief Hariana. 2004. Tumbuhan Obat dan Khasiatnya. Jakarta : Penebar Swadaya.

Aris Santjaka. 2013. Malaria Pendekatan Model Kausalitas. Yogyakarta : Nuha Medika.

Bahaya Penggunaan repellent terhadap Kesehatan Manusia.

ik.pom.go.id/v2012wp.../BahayaDEETpadaIns ect.pdf, diakses tanggal 7 Januari 2015 pukul 11.10 WIB. 
Cahyo Dwi Kuncoro. 2009. Keefektifan Berbagai Konsentrasi Ekstrak Bunga Lavender (Lavandula agustifolia) sebagai Repellent Nyamuk Aedes Aegypti di Loka Litbang P2B2 Banjarnegara Tahun 2009. KTI. Purwokerto : Kementerian Kesehatan RI Politeknik Kesehatan Semarang Jurusan Kesehatan Lingkungan Purwokerto.

Departemen Kesehatan R.I. 2009. Rencana Pembangunan Jangka Panjang Bidang Kesehatan 2005 - 2025. Jakarta : Departemen Kesehatan R.I.

Departemen Kesehatan R.I. Direktorat Jenderal Pemberantasan Penyakit Menular dan Penyehatan Lingkungan.2001. Pedoman Ekologi dan Aspek Perilaku Vektor. Jakarta : Departemen Kesehatan R.I.

Loka Litbang P2B2 Depkes R.I. 2007. Inside Vol. II No. 01/ Tahun 2007. Cimahi : Saejaya Media Sejahtera.
Ririh Yudhastuti. 2011. Pengendalian Vektor dan Rodent. Surabaya : Pustaka Melatii Subiyakto.

Shri J.N. Mathur. 2003. Prospect of Using Herbal Products in The Control of Mosquito Vectors. New Delhi : ICMR Bulletin Vol. 33, No. 1 p : $1-12$.

Subiyakto Sudarmo. 2005. Pestisida Nabatii Pembuatan dan Pemanfaatannya. Yogyakarta : Kanisius.

Suharso dan Ana Retnoningsih. 2005. Kamus Besar Bahasa Indonesia. Semarang : Widya Karya.

Titin Yuniarti. 2008. Ensiklopedia Tanaman Obat Tradisional. Yogyakarta : Media Pressindo. 